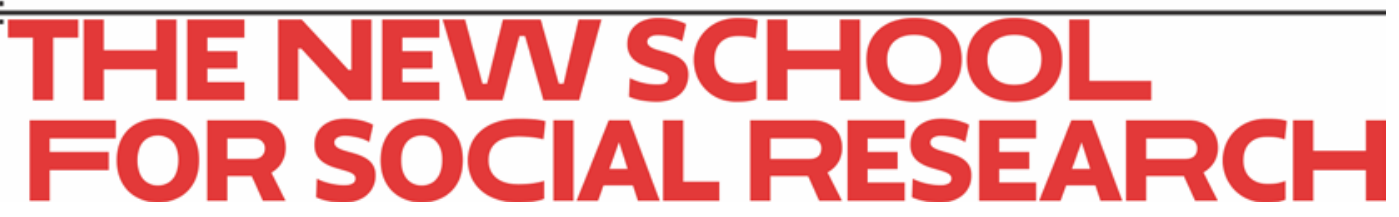

Remzi Baris Tercioglu

\title{
Rethinking growth and inequality in the US: What is the role of measurement of GDP?
}

June 2019; revised February 2020

Working Paper 06/2019

Department of Economics

The New School for Social Research 


\title{
Rethinking growth and inequality in the US: What is the role of measurement of GDP?
}

\author{
Remzi Baris Tercioglu \\ The New School for Social Research
}

\begin{abstract}
Five sectors have increased their contribution to US growth post1973: Professional-business services (PBS), finance, information, healthcare, and arts-entertainment. Among these services, finance, healthcare, and PBS have questionable foundations to be regarded as final consumption. The paper develops a sectoral explanation to stagnation in median income and wages since the mid-1970s by treating finance, healthcare, and PBS as intermediate consumption of the economy. The adjusted real output growth per annum is $16 \%$ lower than the real GDP growth over 1973-2017, yet the decline is 5\% over 1947-1973. Consumption share of GDP declines from $63 \%$ in 1947 to $61 \%$ in 2016 after adjustments despite rising consumerism over the same period. On the income side, the compensation of employees (CE) share of output declines sharply after the 1980 s as more than $90 \%$ of the expenditures on finance, healthcare and PBS are financed out of the CE. The paper contributes to growth and inequality literature by introducing a new measure of real output growth.
\end{abstract}

Keywords: national income accounting; measurement of real output growth; functional distribution of income; labor productivity; inequality.

JEL Codes: E01, E25, D33.

\section{Introduction}

A rising tide lifted all boats in the US until the mid-1970s. After that, however, output growth has almost stopped feeding into median income and wages. Over 1953-1980, real GDP per capita and real median income grew annually at the same rate $(2.1 \%)$, but since 1980 , growth of GDP per capita $(1.7 \%)$ outpaced median income growth $(0.6 \%)$. The same phenomenon can be observed in the productivity gap: Over 1948-1973, productivity and average real wages grew together (annually by $2.3 \%$ and $2.2 \%$ respectively). However, 
from 1973 to 2016 , productivity grew by $1.5 \%$ per annum, but real wages by $0.2 \%$.

This change has two possible explanations. The first explanation is that the US economy did grow but distributed the newly created income very unequally. Piketty et al. (2017) show in their distributional national accounts that top $1 \%$ of income distribution has wiped away almost all benefits of the growth after 1980, therefore there is nothing left to middle and low-income Americans. On the other hand, there is another explanation, questioning whether the problem is with GDP and measurement of growth. Basu and Foley (2013) decompose US value-added into measurable and imputed components and observe that the measurable part correlates strongly with current employment trends, unlike the recent GDP. Assa (2015) treats the output of rapidly growing FIRE services as an intermediate consumption of the economy and arrives at a measure that is highly correlated with employment and median income. Following the second line of explanation, this paper explores the impacts of treating finance, healthcare, and professional-business services (PBS) as intermediate consumption of the economy on US growth rates and distribution of income over 1947-2017.

The reason for focusing on finance, healthcare, and PBS is two-fold. Firstly, they have grown more rapidly than the economy after the mid-1970s when GDP has decoupled from real median income and wages. Figure 1 below gives the distribution of the US value-added in 1947, 1973, and 2017. Over 70 years, real estate, PBS, finance, healthcare, information, arts-entertainment, and education have increased their share in the US GDP continuously, but PBS, finance, and healthcare mainly after 1973. In 1947, the contribution of finance, healthcare, and PBS to the value-added was negligible, just $7 \%$ of the Gross Value Added. Their share rose to $12 \%$ in 1973, and $28 \%$ in 2017. Figure 2 gives the average annual contribution of each industry to real output growth over 1948-1973 and 1974-2018 together with the change between two periods. Manufacturing contributes most to growth over both periods, but its contribution has declined significantly with the change in the structure of production after the mid-1970s. Real estate, government, wholesale, and retail trade were other significant contributors to growth before 1973, but their share in growth likewise declined after that. On the other hand, PBS, finance, information, healthcare, and arts-entertainment have increased their contributions after 1973. In particular, finance, healthcare, and PBS accounted for 0.47 percentage points of the growth in GDP until 1973, and this number has risen to 0.73 post-1973, where real GDP growth has declined from $4.06 \%$ over $1948-1973$ to $2.70 \%$ over 1974-2018.

The second reason for focusing on finance, healthcare, and PBS is their questionable foundations to be treated under final consumption. Assa (2016) argues that financial services are better treated as intermediate consumption because households pay financial fees in their way to consume other goods and services. One may consider credit card fees as an example. The point of departure is to buy a good or service, and credit card fee becomes the cost of the final use. National accounts treat mortgage points, for example, as intermediate consumption of the housing sector, which is not different than other financial 


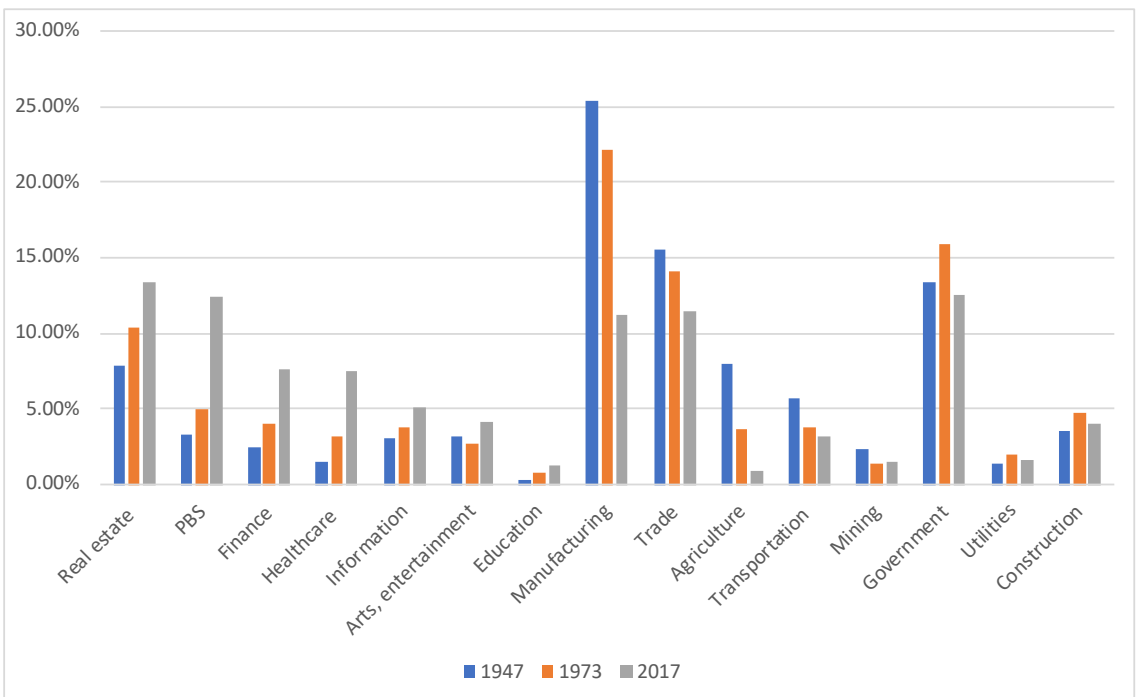

Figure 1: Value-added shares of industries in 1947, 1973 and 2017

Source: BEA's Use Tables before redefinitions at producers' prices

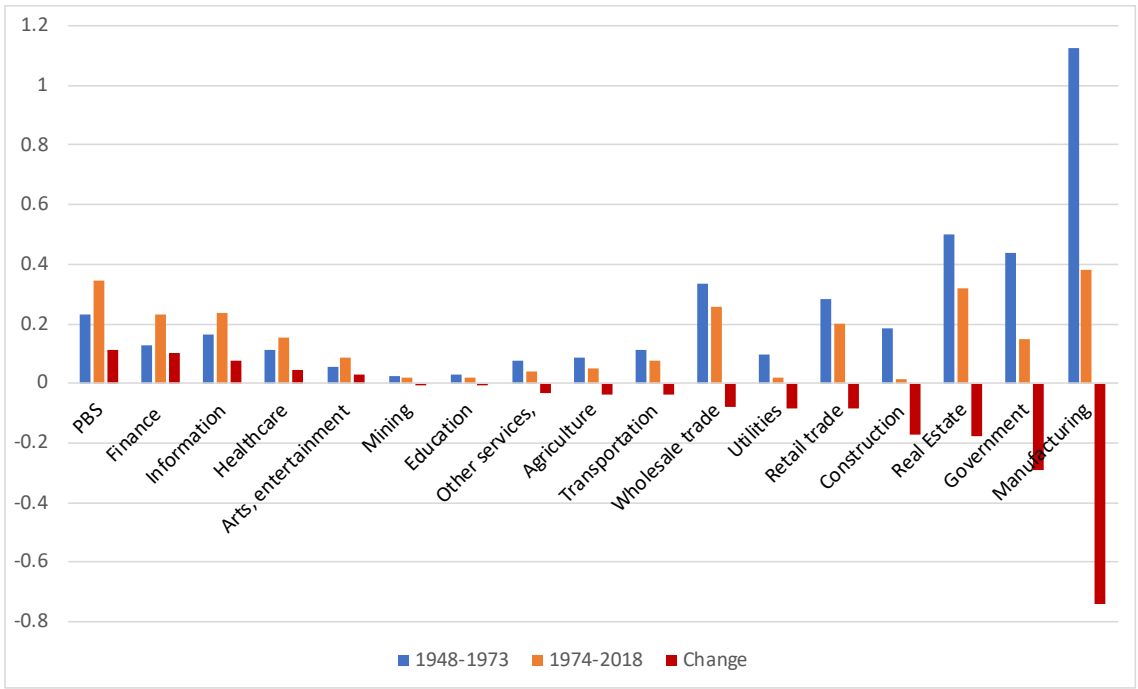

Figure 2: Contributions to Percent Change in Real GDP by Industry Source: BEA's GDP-by-industry data 
fees. In addition to the fee-based income, traditional banking services, which is financial intermediation between lenders and borrowers, have already been controversial among national income accountants because they are not explicitly priced. Assa (2016) offers a solution to the controversy by treating all financial services as intermediate consumption of the economy. One can raise a similar question for healthcare and PBS. Healthcare expenditures can be treated under "necessary overhead costs of a complex industrial nation-state" (Nordhaus and Tobin, 1972, p. 7). Nordhaus and Tobin (1972) shift public health expenditures to intermediate consumption, and private healthcare to investment. Similarly, Stiglitz et al. (2010) argue that healthcare expenditures should be treated under investment because they are additions to human capital. I argue, on the other hand, that healthcare is ordinary maintenance cost of society; therefore, it should be treated as intermediate consumption. The case for accounting fees or attorney costs is quite similar. Expenditures on these services reflect the institutional costs of the US legal system and the complex tax code, which are not direct sources of satisfaction. Consumer-related part of the PBS is treated as intermediate consumption in addition to finance and healthcare in this paper.

The contribution of the paper is developing a sectoral explanation to stagnation in median income and wages by introducing a new measure of real output. Annual growth of the adjusted real output is $16 \%$ lower than real GDP growth over 1973-2017, yet the decline over 1947-1973 is less than 5\%. After taking out finance, healthcare, and PBS expenditures, consumption share of GDP declines from $63 \%$ in 1947 to $61 \%$ in 2016 despite rising consumerism over the same period. On the income side, inequality between wages and profits rises substantially after adjustments as most of the expenditures on finance, healthcare, and PBS are financed out of the compensation of employees. The current treatment of NIPAs not only overestimates growth and consumption but also obscures the sharper wage-profit inequality, thus showing American capitalism better performing and less unequal.

The paper is organized into six sections. Section 2 discusses the changing structure of growth post-1973 and the rationale of treating finance, healthcare, and PBS as intermediate consumption. In section 3, real output growth is measured with the new metric before and after 1973, and distribution of expenditures is adjusted. Section 4 discusses adjustments to the income side of accounts and explores their impact on the functional distribution of income. In section 5 , the current investigation is linked to the relevant literature. Section 6 discusses some implications of the results for the US political economy.

\section{Sectoral decomposition of US growth}

Until 1973, productivity growth fed into real wages of production and nonsupervisory workers that make around $80 \%$ of total employees in the US. Similarly, GDP per capita went hand in hand with real median income until 1980. That was the period when growth lifted all boats, including working-class Americans. Labor productivity has continued growing after 1973 (1.5\% annually); 
however, real wage growth has stagnated since then ( $0.2 \%$ annual growth), as Figure 3 shows. Productivity gains stopped feeding into paychecks of workers. However, productivity growth is believed to be the engine of wage growth in the long-run. This puzzle has been explained by rising capital share of income and unequal distribution of labor income to workers. On the other hand, the problems with measurement of real output growth have attracted much less attention.

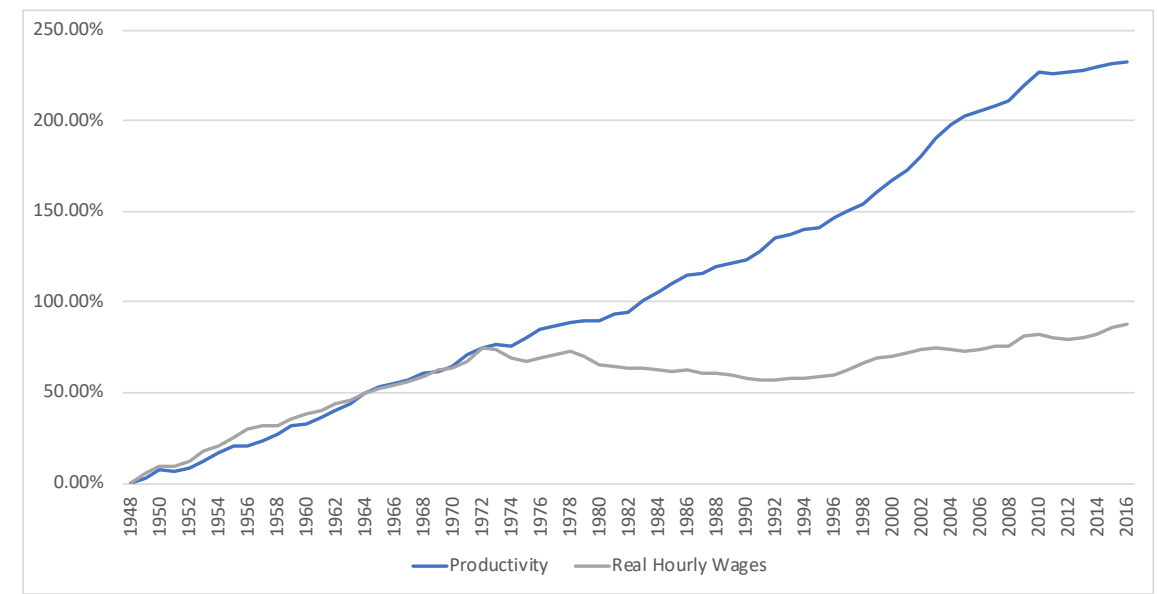

Figure 3: Labor productivity and real wage growth (in 2009 dollars)

Source: FRED Data and the EPI's State of Working America Data Library

Sectoral decomposition of the US value-added changed radically during the 1970s. As Figure 1 shows, US growth heavily depended on manufacturing, which made more than $20 \%$ of the value-added until the mid-1970s. When retail-wholesale trade, real estate, and government are added, one reaches more than $60 \%$ of the gross value-added in 1947 and 1973. In 2017, this share fell below $50 \%$. Likewise, their contribution to growth declined from $66 \%$ over 1948 1973 to $49 \%$ over 1974-2018, as Figure 2 displays. On the other hand, five sectors have increased their contribution to economic growth after 1973: PBS, information, finance, healthcare, and arts-entertainment. Their average cumulative contribution to 1948-1973 growth was 16\%, but they accounted for almost $40 \%$ of post-1973 growth. Do rapidly growing sectors create a measurement problem for growth and productivity?

If these services contribute to the final use of households, then there is just a shift of sectoral balance within GDP, which will not change real output growth. However, if their contribution to final use is controversial, post-1973 growth and productivity will also be questionable because they depend heavily on these sectors. Therefore, after decomposing post- 1973 growth to find rapidly growing sectors, I apply a second criteria and analyze the contribution of these sectors to the final product. 
Final products are distinguished from intermediate inputs according to their direct contribution to current and future consumption of households. Kuznets (1951) discusses final-intermediate product distinction based on "set of goals, whose satisfaction is treated as a positive contribution" (Kuznets, 1951, p. 179) to social welfare and Eisner (1988) argues that national accounts should measure final products that are additions to economic welfare. From the welfare perspective, among the more rapidly growing sectors than the economy post1973, the contribution of healthcare, finance, and PBS to final use of households is questionable as discussed respectively in the following three subsections. ${ }^{1}$

\section{$2.1 \quad$ Healthcare}

Currently, most of the output of healthcare services are reported under personal consumption expenditures and added to GDP. A small part of health services, such as work-related medical tests, is under intermediate consumption of firms. ${ }^{2}$ Employer contributions for health and life insurance are reported under the compensation of employees (supplements to wages and salaries) and imputed to personal consumption expenditures. ${ }^{3}$ Government expenditures on healthcare are also imputed to final consumption expenditures of households.

The treatment of healthcare expenditures under final consumption was not a big problem when healthcare was a small part of GDP until the 1970s. However, as expenditures on health have risen after the 1970s, their treatment in national accounts has become controversial among economists. Nordhaus and Tobin (1972), in their search for a measure of economic welfare, treat public health expenses as intermediate consumption ${ }^{4}$ due to their collective nature, and shift private healthcare to investment. Stiglitz et al. (2010) also recommend to treat expenditures on healthcare as fixed asset formation even though they discuss healthcare under defensive expenditures, which are generally defined as intermediate consumption. They argue that health expenditures are maintenance costs of human capital. Foley (2013), on the other hand, argues that healthcare spending is the cost of capitalist production, which creates environmental problems, stress, and poor working conditions.

It is understandable to keep track of the overall health of the society because a good state of health is an indispensable part of the well-being. However, treating healthcare expenditures as investment is misleading because these expenditures are at best instrumental for reaching that goal. ${ }^{5}$ Stiglitz et al. (2010)'s

\footnotetext{
${ }^{1}$ Foley (2013) says, "Capitalist production creates health problems through environmental degradation and increased stresses and dangers of production environments. It is not clear that there is any inherent human need for legal or financial services, which seem rather to be needs produced by the social relations of capitalism itself" (Foley, 2013, p. 3).

2If employers are covering the cost of work-related medical tests, they are reported as business expenses and subtracted from their value-added. However, if employees are paying for them, they are treated as final consumption of households (Assa, 2015, p. 14).

${ }^{3}$ This imputation makes around one-fourth of all healthcare expenditures in 2016 .

${ }^{4}$ They call these expenditures as instrumental expenditures, which are "necessary overhead costs of a complex industrial nation-state" (Nordhaus and Tobin, 1972, p. 7).

${ }^{5}$ Rent-seeking is very common in the health sector through insurance and drug companies.
} 
maintenance cost formulation does not directly imply investment because SNA defines only major improvements that increase capacity as investment expenditures. In contrast, ordinary maintenance is treated as input cost of production (SNA 1993, p. 13). Major improvements are results of R\&D expenditures on healthcare, which are already treated as investment in national accounts, and my treatment here does not change this. I argue that healthcare services fit better to the ordinary maintenance category, thus to intermediate consumption.

In the current NIPAs, the health sector consists of five parts: Healthcare (hospitals, doctors' and physicians' offices), health insurance, health-related expenditures on goods (drugs and medical equipment), health-related fixed investment (buildings) and government expenditures on health. Health insurance is under finance and insurance; therefore, it is treated under finance in the next section. Healthcare fixed investment is left in GDP because it is not an intermediate consumption. Expenditures on durable and nondurable health-related goods and healthcare services, including government expenditures on health, are treated as intermediate consumption in the paper. ${ }^{6}$ Figure 4 shows the evolution of expenditures on different components of the health sector since 1947.

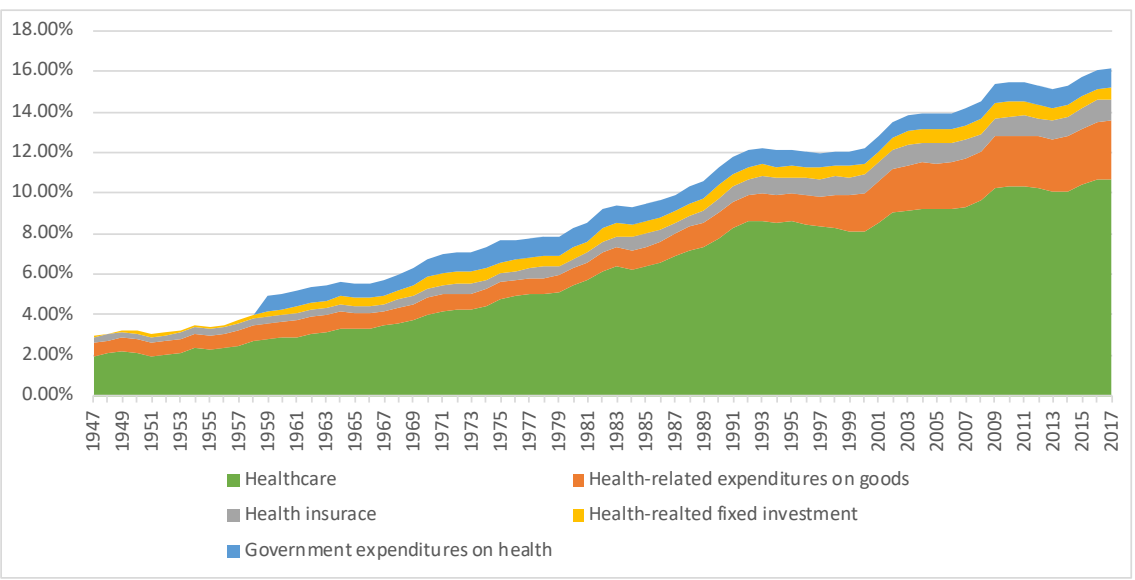

Figure 4: Health expenditures of the US, 1947-2017 (percent of GDP)

Source: National Income and Product Accounts

Figure 4 highlights that health expenditures have increased radically since 1947. These expenditures were making around 5\% of GDP until 1970; however,

Government policies (or lack of policies) also have significant impacts on the price of healthcare and drugs. Stiglitz et al. (2010) point to pricing problem in healthcare because the process is not transparent. Mazzucato (2018) mentions the rising number of "drugs with little or no therapeutic value (Mazzucato, 2018, p. 208). However, even the system were perfectly competitive, not all healthcare services would result in a good state of health.

${ }^{6}$ Social assistance is treated under healthcare because in I/O Tables over 1947-1962, healthcare data include social assistance. However, this is not a universal convention, and some other countries report social services separate from healthcare. 
today, they account for more than $16 \%$ of GDP. The most significant part of expenditures contains hospitals, doctors' offices, laboratories, nursing, and residential care services. Medical equipment and pharmaceutical expenditures are the second most prominent component of the health sector, and their cost has been rising since the 1990s.

\section{$2.2 \quad$ Finance and insurance}

There has been a long controversy among national income accountants on how to treat financial services in the NIPAs. Assa (2015) describes three types of financial income and different treatment of each in national accounts. The first income type is capital gains, which are left out of GDP because of not being productive. If a bank, for example, is making profits from the valuation of its assets, this income is not recorded as profits in national income accounts. The second type of income is interest income coming from financial intermediation services, which are today known as Financial Intermediation Services Indirectly Measured (FISIM). FISIM income is treated as intermediate consumption of firms and subtracted from their value-added. The third category is the income generated from fee-based financial services, which is treated as a final product in the NIPAs (Assa, 2015, p. 3). There is no controversy on how to treat capital gains; however, treatment of FISIM and fee-based income has been controversial.

Christophers (2011) argues that intermediation services had not been counted in banks' output in many advanced economies until the SNA $1968^{7}$ because they are not explicitly priced. When banks are treated like other businesses, their value-added becomes negligible or even negative (Christophers, 2011, p. 124) since the fee-based income is generally lower than the input costs of banks. This is known as the banking problem, and Mazzucato (2018) sees it as the tension between the decreasing role of banks in stimulating growth and their increasing ability to generate income (Mazzucato, 2018, p. 105). National income accountants have tried to overcome the so-called banking problem by imputing the value of financial intermediation services to banks' output.

BEA refers to these services as "financial services furnished without payment" or as "implicitly priced services." For example, banks may provide some services - such as processing of checks, disbursing or transferring funds when needed, protecting deposit funds, and investment services - without charging explicit fees. To account for such services, the NIPAs include an imputation of the value of these services because they are omitted by the standard measure of output based on revenue from fees or prices, which is used for most industries (Hood, 2013, p. 8).

\footnotetext{
${ }^{7}$ Christophers (2011) defines SNA 1968's treatment of finance as implicitly productive because intermediation services were imputed to banks' output but subtracted from the rest of the value-added either by defining a nominal sector whose only input is intermediation services as in the UK or decreasing value-added of users of intermediation services as in France. The US followed SNA 1953's suggestion of imputing wages and profits of the banking sector to banks' output, but "US case is very much an anomaly" (Christophers, 2011, p. 130).
} 
The difference between interest rates on loans and deposits times volume of non-bank capital is defined as FISIM income, and this amount is imputed to banks' output. The imputed amount was "assumed to be fully consumed by financial and non-financial companies, so none made it through into final output" (Mazzucato, 2018, p. 107). However, with the SNA 1993, FISIM income is started to be distributed to households and firms. When firms use intermediation services, the market value of the service is still treated as intermediate consumption and subtracted from their value-added. However, when households use these services, FISIM is imputed to personal consumption expenditures. Mazzucato (2018) argues that this treatment increased GDP more with the household debt boom of the 2000s.

On the other hand, Assa (2015) argues that intermediation services do not produce final use-value for households, therefore imputed FISIM should be subtracted from personal consumption expenditures just as it is deducted from value-added of firms. People use bank loans, not as a source of satisfaction, but because they cannot finance their expenditures out of savings. In addition to FISIM, Assa (2015) discusses the inconsistent treatment of fee-based financial services in national income accounts. To Assa (2015), people do not consume fee-based services per se, but they pay for these services in their way to consume other goods and services.

From a theoretical point of view, however, the non-FISIM part of financial services, that is, the fee-based income in the GDP-by-output approach, is as problematic as interest-based income. Finance, in its various manifestations, ultimately involves the transfer of money. Unlike other commodities, money has no use value, only an exchange value. In fact it is exchange value par excellence (p. 6).

Following Assa (2015), financial services are treated as intermediate consumption of the economy in this paper. ${ }^{8}$ Some services under real estate such as brokerage and property management are shifted to finance, since they are intermediate in reaching housing services, just like FISIM and fee-based services. Figure 5 above gives the evolution of financial expenditures over 1947-2017. These expenditures were just $2 \%$ of GDP in 1947, and they became more than $7 \%$ in 2017. Imputed FISIM and fee-based expenditures rise hand in hand post-1980.

\subsection{Professional-business services}

Professional and business services are legal services, design, research and technical services, administration, and waste management services in the NIPAs. PBS is a mixed bag, and firms use most of its output as intermediate consumption ( $73 \%$ in 2016), and the remaining part is added to GDP (27\% in

\footnotetext{
${ }^{8}$ Under finance, Federal Reserve banks, credit intermediation, and related activities; Securities, commodity contracts, and investments; Insurance carriers and related activities and Funds, trusts, and other financial vehicles are subtracted from GDP.
} 


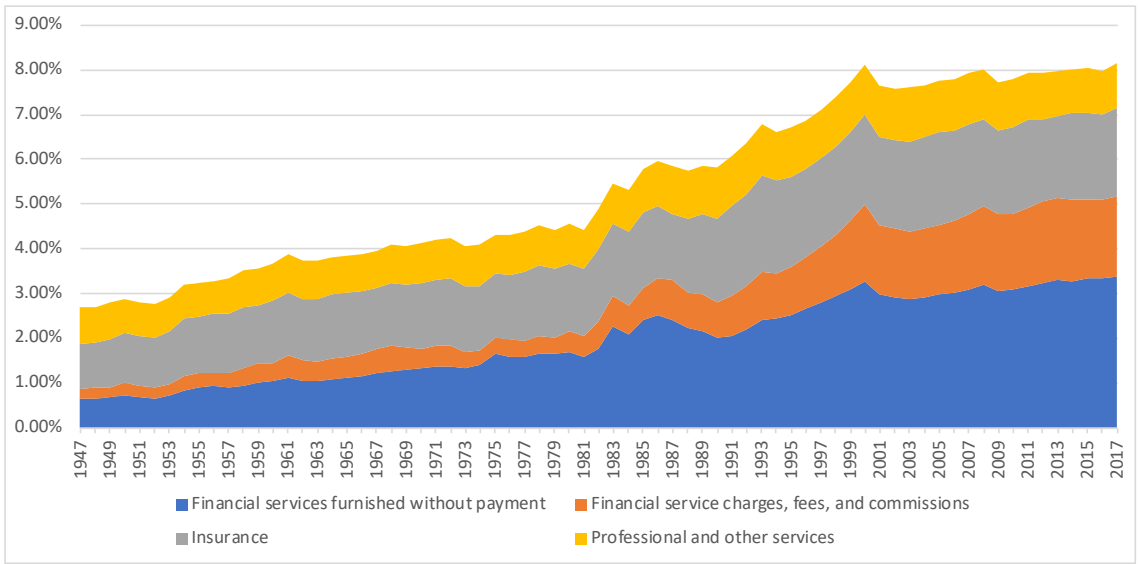

Figure 5: Financial and professional services, 1947-2017 (percent of GDP)

Source: National Income and Product Accounts

2016). Among final expenditures on PBS, investment makes the most significant part ( $57.4 \%$ in 2016 ) because of the R\&D expenditures and fixed investment on computer systems. These expenditures are not adjusted because they generate future income streams; thus, they are not intermediate consumption of firms. Some PBS services (computer systems design, management of companies and enterprises) are only used by firms, and they do not appear under final expenditures. For households, legal services make the most significant part of personal consumption expenditures on PBS (40\% in 2016), and discussion in this section focuses mainly on this part of PBS, which is around 1\% of GDP in 2017.

PBS services are not direct sources of satisfaction for households. One can discuss these services under Kuznets (1953)'s "occupational expenses", which are the expenditures made in the way to earn a living. Kuznets (1953) gives trade union dues and work-related expenses as examples, and one can extend this argument to legal and accounting fees. Consider fees paid to accountants for filing tax returns. This is attached to earning income, and people spend their time and money on this issue because of the complex tax code of the US. This expenditure is hardly adding to the satisfaction of consumers. One can also raise the same question for fees paid to attorneys and other litigation costs. People do not consume these services per se, but they pay for them in order to reach a particular outcome. If fees are in return to a service, which is related to production or consumption, they become a cost of the economic outcome of the legal process. If an immigrant is seeking a US work permit, she will need to hire a lawyer to defend her legal status, and money paid to lawyers will become intermediate in being able to work. Even when lawsuits are not directly economic (one might consider child custody cases as a result of abounding divorces in modern societies), legal fees can still be considered socially 
regrettable expenditures for producing the value-added of modern economies. ${ }^{9}$

\section{Adjusting growth and distribution of expen- ditures}

GDP is calculated through three theoretically equivalent methods: expenditures approach, income approach, and value-added approach. From the expenditures side, final expenditures are measured as the sum of personal consumption (C), private investment (I), net exports (NX), and government expenditures $(\mathrm{G})$.

$$
G D P=C+I+N X+G
$$

GDP by the income is the sum of Compensation of Employees (CE) paid, Gross Operating Surplus (GOS), Net Taxes (NT) (taxes on production and imports, less subsidies), and Statistical Discrepancy (SD).

$$
G D P=C E+G O S+N T+S D
$$

Value-added of industries are calculated through subtracting intermediate consumption (IC) of firms from their output (O). Gross Value Added (GVA) is defined as the sum total of value-added of each industry i.

$$
G V A=\sum_{i}\left(O_{i}-I C_{i}\right)
$$

When taxes on products less subsidies (T) are added to GVA, one arrives at GDP by the value-added.

$$
G D P=G V A+T=\sum_{i}\left(O_{i}-I C_{i}\right)+T
$$

If industry $\mathrm{i}$ is using all output of industry $\mathrm{j}$, the market value of the product will be reported under $I C_{i}$ and subtracted from $O_{i}$, thus leaving value-added of industry $i$ as its net product. The output of industry $j$ will not be included in GDP since it is an intermediate product, which is consumed by the industry i. If the output of industry $\mathrm{j}$ were classified as a final product; instead, the market value of the output would be added to GDP.

Reclassification of expenditures for intellectual property products in 2013, following the advice of the System of National Accounts (SNA) 2008, is a good example. Before 2013, R\&D and entertainment originals were treated as intermediate consumption of firms and subtracted from their value-added. However, since 2013, the Bureau of Economic Analysis (BEA) has been measuring these expenditures under investment in intellectual property products. The BEA

\footnotetext{
${ }^{9}$ Interestingly, William Petty, who did the first national income estimations, treated "great professions" as facilitators of production and maintenance costs of the social order (Mazzucato, 2018, p. 25).
} 
added expenditures for $\mathrm{R} \& \mathrm{D}$ and entertainment originals ( $\$ 560$ billion in 2013) to nominal GDP, which increased by 3.6\% in July 2013 (Goodwin et al., 2015, p. 113). ${ }^{10}$

In order to treat finance, healthcare, and PBS as intermediate consumption, I do the opposite. I subtract final expenditures on finance, healthcare, and PBS from consumption, investment, net exports, and government spending to get the adjusted GDP by the expenditures. Then, I impute the deduction to the CE and GOS by using household survey data of the Bureau of Labor Statistics (BLS) in section 4 to adjust GDP by the income. I discuss an equivalent adjustment to GDP by the value-added in the Appendix. In this section, real output growth and distribution of expenditures are adjusted, respectively.

Real GDP of the US grew by $4 \%$ annually over 1947-1973, and output growth did feed into real median income and wages over the same period. Over 19732017 , growth per annum declined to $2.6 \%$, but real median income and wage growth have almost stopped. This anomaly has raised the question of whether or not real output growth is measured correctly. To see the role of finance, healthcare, and PBS in this puzzle, real output growth is adjusted before and after 1973 in Figure 6.

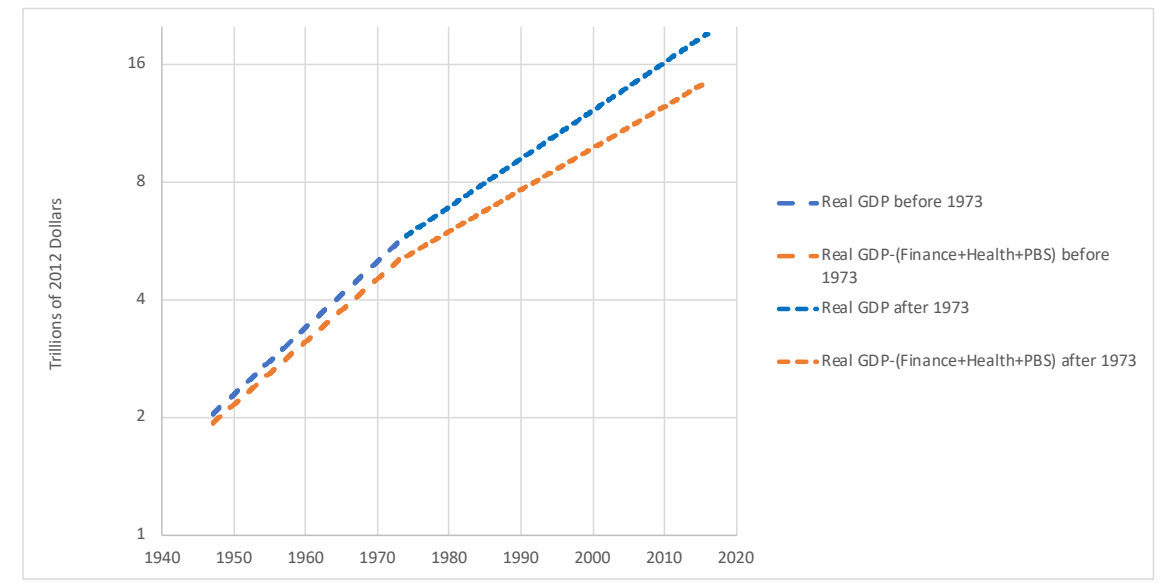

Figure 6: Growth of real output before and after adjustments over 1947-2017

Source: The BEA's Use Tables and FRED Economic Data

Lines are fitted logarithms; therefore, slopes indicate growth rates of real output. Until 1973, adjustments do not change growth rates more than 5\%, which is an expected result because finance, healthcare, and PBS were minor contributors to US GDP until the 1970s. After 1973, the gap between lines becomes more significant, and the effect of adjustments triples. The annual growth rate of adjusted real output after 1973 is $16 \%$ less than real GDP growth.

\footnotetext{
${ }^{10}$ Growth rate in 2013 is not affected much by this adjustment because past expenditures on intellectual property products were also added to past GDP's.
} 
In per capita terms, the difference rises to $25 \%$ per annum over 1973-2017. This finding suggests that an essential part of the gap between productivity and real wages (or between per capita output growth and median income) is the result of how we treat finance, healthcare, and PBS in national accounts. ${ }^{11}$

Figure 7 shows GDP by the expenditures before and after adjustments in 1947, 1980, and 2016. Consumption is the largest part of GDP in 1947, 1980 and 2016. Its share in total expenditures declines from $65 \%$ to $60 \%$ over $1947-1980$ and rises to $69 \%$ in 2016 . This U-shaped pattern in consumption resembles the evolution of the US inequality. Private investment and government expenditures make $15 \%$ and $16 \%$ of GDP in 1947. Their shares in GDP increase significantly until 1980 and decline after that to almost 1947 levels by following an inverse-U shaped path. The most significant difference is in net exports. The US economy had trade surplus around 4\% of GDP in 1947, trade balance in 1980, and a $3 \%$ deficit in 2016.

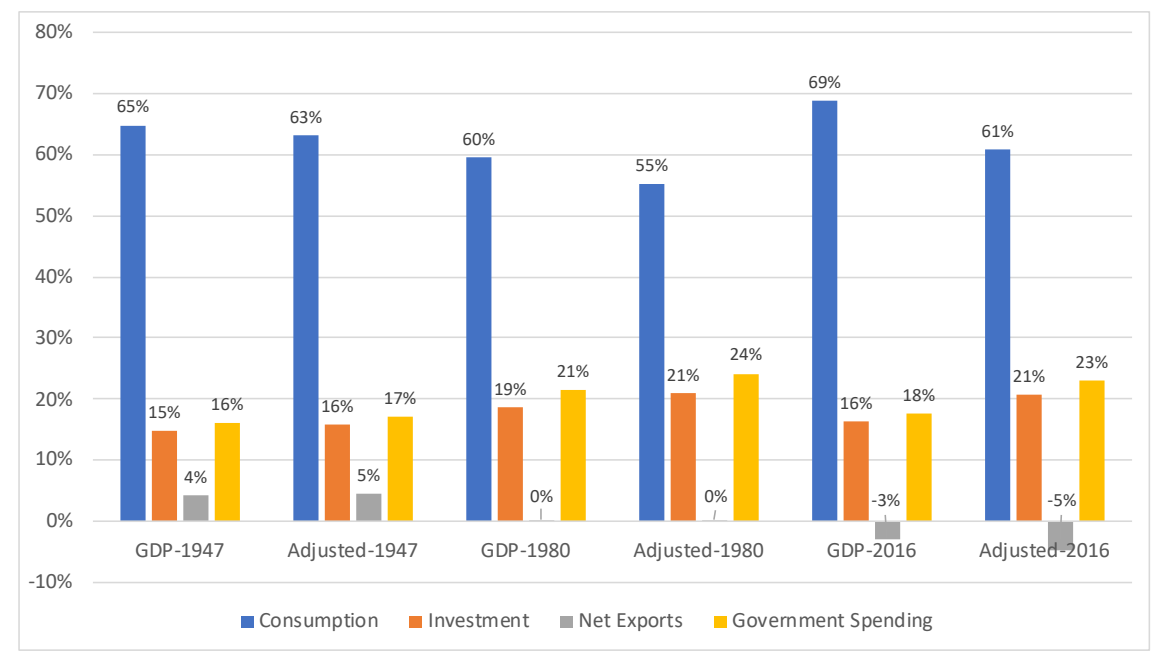

Figure 7: Decomposition of GDP before and after adjustments in 1947, 1980 and 2016

\section{Source: The BEA's Use Tables}

In the adjusted accounts, one can observe a similar U curve in consumption share, which falls from $63 \%$ in 1947 to $55 \%$ in 1980; then, it rises back to $61 \%$ in 2016 as a result of rising consumerism after 1980. However, the 2016 share of consumption is still below the 1947 level, showing that consumerism has brought

\footnotetext{
${ }^{11}$ GDP-(Finance+Health+PBS) is deflated by the GDP deflator after the adjustments. When each deduction is deflated by its price deflator, annual real GDP(Finance+Health+PBS) growth over 1947-1973 becomes 3\% lower than real GDP growth. The effect of the adjustment rises to $8 \%$ over $1973-2017$ and $12 \%$ in per capita terms. However, sectoral price deflators are not without problems as it is hard to capture the timing of the quality change.
} 
lower consumption compared to 70 years ago when rising financial expenditures, healthcare, and professional services are taken out of consumption.

Another noteworthy result is the constant share of private investment after adjustments in 1980 and 2016. Rising profits and falling investment share of GDP is one of the questions of the US political economy. Stiglitz (2019) explains this anomaly through firms' willingness to increase their market power by using profits instead of investing more. Mazzucato (2018) points to share buybacks as a strategy to channel rising profits to monopoly power rather than contributing to the future of the economy. Adjustments offer a measurement dimension to this question. Maybe investment share is not declining, but aggregate expenditures are being inflated. Investment share rises by $5 \%$ from 1947 to 1980 in adjusted accounts, just like the current GDP, and then stays there after 1980 .

Government spending share also does not change in adjusted accounts over 1980-2016. Despite the attempts to downsize the government, it still stands as an essential part of the aggregate demand. The last impact of adjustments is to net exports. Net exports decline to -5\% of GDP in 2016 from 5\% in 1947 after adjustments. Taking out financial products and professional services from exports decreases the international competitiveness of the US economy sharply.

\section{Distribution of income}

This section aims to adjust GDP by the income by estimating how much of expenditures on finance, healthcare, and PBS are financed out of the compensation of employees. In order to estimate sources of expenditures, the Consumer Expenditures Survey (CEX) of the BLS becomes a valuable data source. ${ }^{12}$ Distribution of income over quintiles and functional distribution of income are adjusted respectively in the following two subsections by using survey data over 1985-2015.

\subsection{Distribution of income over quintiles}

CEX provides three types of information. The first is the means of aggregate expenditures of quintiles together with before-tax incomes. Healthcare has a separate entry in CEX, but finance and professional services do not. These expenditures are approximated by the miscellaneous expenditures category. ${ }^{13}$ Figures 8 and 9 give the distribution of aggregate health and finance-PBS expenditures of quintiles for selected years over 1985-2015.

Figure 8 shows that the share of bottom $60 \%$ in aggregate health expenditures declines, whereas the top 20\%'s share rises continuously over 1985-2015, in particular after 2000. In 2015, the share of the top $20 \%$ in aggregate health

\footnotetext{
${ }^{12}$ Annual survey data started in 1984, and current surveys are conducted with more than 130,000 consumer units.

${ }^{13}$ BLS collects safety deposit box rental, funerals, cemetery lots, union dues, and occupational expenses in addition to financial and professional expenditures under miscellaneous expenditures.
} 


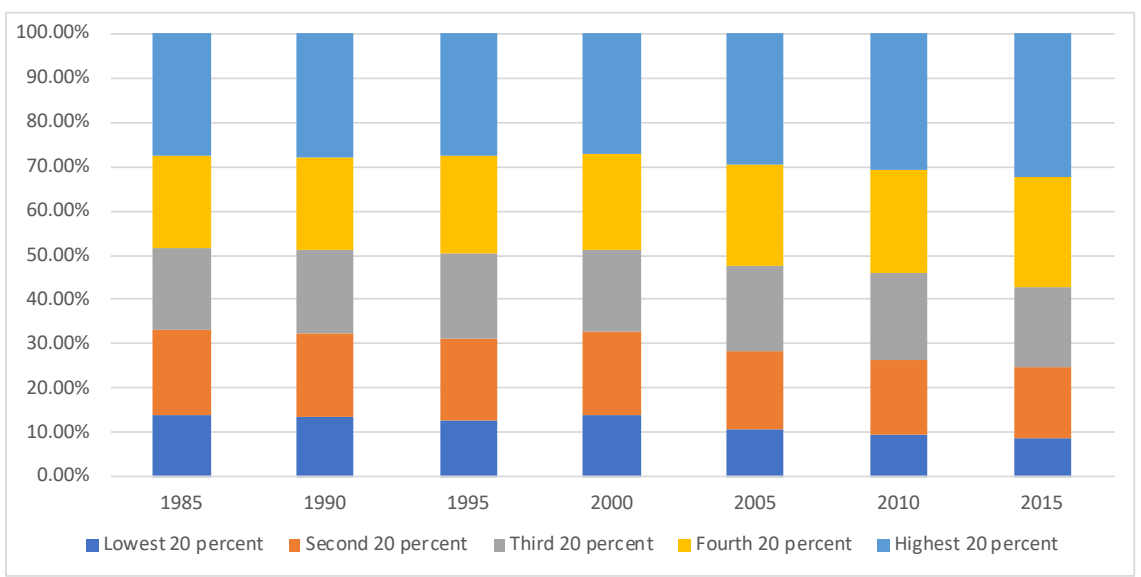

Figure 8: Distribution of healthcare expenditures over quintiles

Source: CEX Expenditure Tables

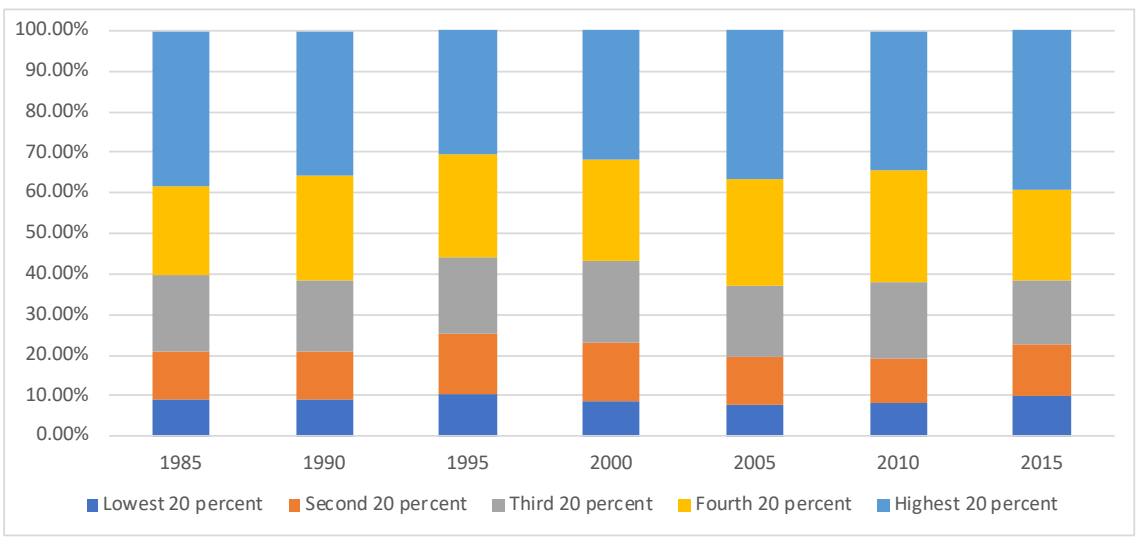

Figure 9: Distribution of finance-PBS expenditures over quintiles

Source: CEX Expenditure Tables 
expenditures was $33 \%$, and the bottom $60 \%$ is $43 \%$. For finance-PBS, the distribution of expenditures is even more unequal. In 2015, the top $20 \%$ made $39 \%$ of aggregate expenditures, which is more than the bottom 60\%'s share (38\%). As can be seen from Figure 9, finance-PBS distribution in 1985 and 2015 are similar though there are some yearly variations.

The second type of information available in CEX is the distribution of beforetax income over quintiles. Aggregate deductions of healthcare $(\mathrm{H})$ and financePBS (FPBS) can be imputed by using expenditures shares and incomes of quintiles to before-tax incomes of quintiles as follows.

$$
\operatorname{adjusted}\left(\frac{Y_{i}}{G D P}\right)=\frac{Y_{i}-\left(h_{i} * H\right)-\left(f p b s_{i} * F P B S\right)}{G D P-H-F P B S} \forall i=1, \ldots, 5
$$

where $Y_{i}$ is the before-tax income of quintile $\mathrm{i}, h_{i}$ is the share of quintile $\mathrm{i}$ in aggregate health spending and $f p b s_{i}$ is the share of quintile i in aggregate finance-PBS spending. Figure 10 gives Lorenz curves with Gini coefficients for 1985 and 2015 before and after adjustments.

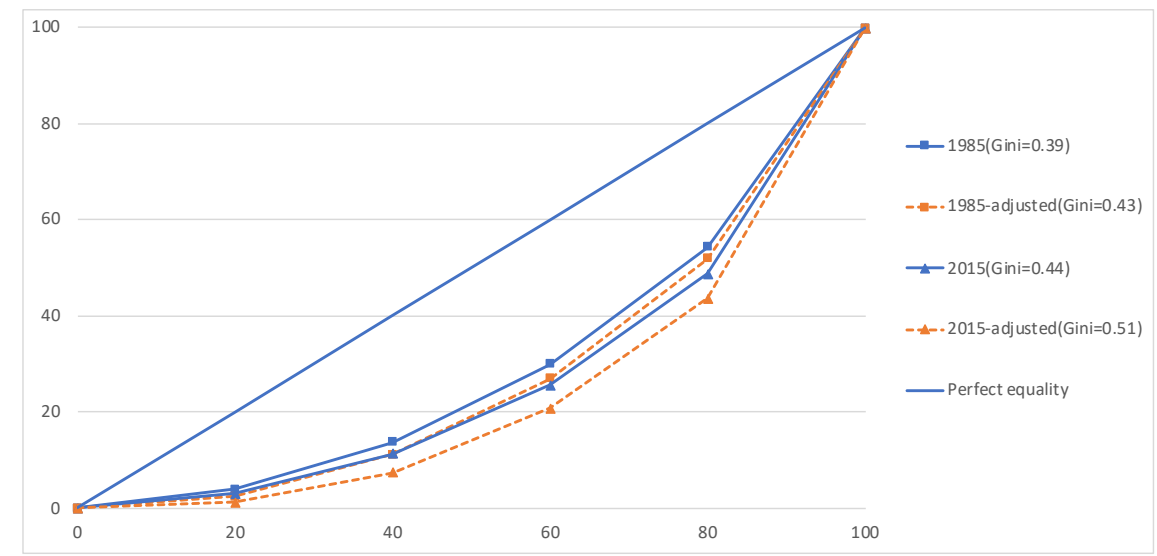

Figure 10: Lorenz Curves before and after adjustments in 1985 and 2015

Source: CEX Tables and the BEA's Use Tables

US income distribution over quintiles has become unequal from 1985 to 2015 due to a rising share of top 20\%, as Figure 10 indicates. Gini coefficient rises from 0.39 to 0.44. After adjustments, Lorenz curves shift outward, and distributions become even more unequal. Gini coefficient of adjusted distribution rises from 0.43 to 0.51 . Although high-income households account for more of the aggregate health, finance, and PBS expenditures, low incomes are hit more by adjustments because a smaller part of aggregate expenditures is still high compared to their income. Results imply that rising healthcare, finance, and PBS costs of American households hit incomes of low-income groups more than the top $20 \%$. 


\subsection{Functional distribution of income}

The third type of information available in CEX is the decomposition of income of each quintile to its sources. The functional distribution of income is adjusted in this section by using sources of income. One problem is that CEX income categories do not match with the NIPA types of income. The NIPA decomposition of income (CE, GOS, and NT) is taken as the benchmark here since, in the end, the NIPA aggregates are adjusted. To this end, CEX income sources are reorganized in order to be compatible with the NIPA definitions of $\mathrm{CE}$ and GOS.

I start with money income before taxes. I subtract other income (scholarships, fellowships not based on working), social security (private and government), and other transfers (food stamps, public assistance) from before-tax income in order to arrive at income before taxes and transfers. I add unemployment and workers' compensation to wages and salaries to arrive at $\mathrm{CE}$, which includes supplements in addition to wages. Lastly, I add self-employment income to interest, dividends, and rental income to arrive at GOS. ${ }^{14}$

This way, I decompose before tax and transfer income of each quintile to CE and GOS. One should be careful in interpreting this decomposition as capitallabor split because self-employment income is shifted totally to GOS instead of being distributed to labor and capital according to their shares. Therefore, the CE share here is less than the conventional labor share of income. Moreover, GOS also includes depreciation in addition to profits, interest, rent, and selfemployment income; thus, its share is much more than the capital share.

Based on the decomposition of income, CE and GOS shares of healthcare expenditures are calculated in the following way.

$$
C E^{\text {health }}=\frac{\sum_{i=1}^{5} h_{i} w_{i} y_{i}}{\sum_{i=1}^{5} h_{i} w_{i} y_{i}+\sum_{i=1}^{5} h_{i}\left(1-w_{i}\right) y_{i}}
$$

and

$$
\text { GOS }^{\text {health }}=\frac{\sum_{i=1}^{5} h_{i}\left(1-w_{i}\right) y_{i}}{\sum_{i=1}^{5} h_{i} w_{i} y_{i}+\sum_{i=1}^{5} h_{i}\left(1-w_{i}\right) y_{i}}
$$

where $w_{i}$ represents the share of $\mathrm{CE}$ in the income of quintile $\mathrm{i}$ and $y_{i}$ represent income share of quintile i. I similarly calculate CE and GOS share of Finance and PBS expenditures. Table 1 below gives these shares for 1985, 2000, and 2015. It is easily seen that almost all expenditures on these services are financed out of CE. However, one can also observe a trend of rising GOS share in financing these services over 1985-2015. This is not surprising because the profit type income of top percentiles has risen after the 1980s, and this group spends more on healthcare, finance, and PBS as distribution figures show. Despite this trend, the share of $\mathrm{CE}$ does not fall below $90 \%$ over the sample.

\footnotetext{
${ }^{14}$ In the NIPAs, proprietors' income is reported under net operating surplus, and I follow the same methodology. GOS is preferred instead of net operating surplus because I aim to adjust GDP by the income, which includes depreciation.
} 


\begin{tabular}{|c|c|c|c|}
\hline & 1985 & 2000 & 2015 \\
\hline \hline CE share of health expenditures $\left(C E^{\text {health }}\right)$ & $99.3 \%$ & $93.2 \%$ & $91.4 \%$ \\
\hline GOS share of health expenditures $\left(G O S^{\text {health }}\right)$ & $0.7 \%$ & $6.8 \%$ & $8.6 \%$ \\
\hline CE share of finance-PBS expenditures $\left(C E^{f p b s}\right)$ & $95.6 \%$ & $92.9 \%$ & $91.1 \%$ \\
\hline GOS share of finance-PBS expenditures $\left(G O S^{f p b s}\right)$ & $4.4 \%$ & $7.1 \%$ & $8.9 \%$ \\
\hline
\end{tabular}

Table 1: Shares of CE and GOS in expenditures on healthcare and finance-PBS

Source: CEX Tables

If total health deduction is $\mathrm{H}$ and Finance+PBS deduction is FPBS, then adjusted CE and GOS shares of GDP can be calculated as follows.

$$
\begin{gathered}
\operatorname{adjusted}(C E)=\frac{C E-\left(C E^{\text {health }} * H\right)-\left(C E^{f p b s} * F P B S\right)}{G D P-H-F P B S} \\
\operatorname{adjusted}(G O S)=\frac{G O S-\left(G O S^{\text {health }} * H\right)-\left(G O S^{f p b s} * F P B S\right)}{G D P-H-F P B S}
\end{gathered}
$$

I calculate these ratios for five years, starting with $1985 .{ }^{15}$ Figure 11 shows GDP by the income before and after adjustments. Income inequality between $\mathrm{CE}$ and GOS increases after adjustments because rising healthcare, finance, and PBS expenditures are mostly financed out of wage income. This happens even though CE shares in Table 1 decline because higher expenditures on healthcare, finance, and PBS after the 2000s dominate the opposite effect. ${ }^{16}$

A noteworthy result is that the GOS share surpasses the CE share of output during the 2000s after adjustments. This is compatible with higher investment share of aggregate demand after adjustments to the GDP by the expenditures in Section 3. This opens a channel from rising profit share to aggregate demand, which can be evaluated as support to profit-led demand theories. However, output growth declines substantially after adjustments over 1973-2017, and this shows that the negative impact of lower wages on aggregate demand is more dominant than the positive effect of rising profits. As Taylor and Ömer (2019) argue, the US economy cannot be strongly profit-led because of the stagnant growth and employment in the last decades.

In order to complete the analysis, productivity is adjusted and plotted with average compensation over 1985-2015 in Figure 12. ${ }^{17}$ Adjustments reduce productivity growth by $15 \%$ and $\mathrm{CE}$ by $55 \%$, thus confirming rising inequality between wages and profits after treating healthcare, finance, and PBS as intermediate consumption of the economy. Productivity grows even after adjustments, but average adjusted compensation stagnates since the 2000s, thus creating a productivity gap.

\footnotetext{
${ }^{15}$ CEX data were published for 1960-61 and 1972-73 and then annually after 1984. However, the quintile distribution of expenditures is available after 1984 .

${ }^{16}$ Net taxes are not adjusted, and they increase slightly due to the denominator effect.

${ }^{17}$ Productivity and compensations are deflated by the GDP-deflator. When compensations are deflated by the PCE deflator of the BEA, results do not change significantly.
} 


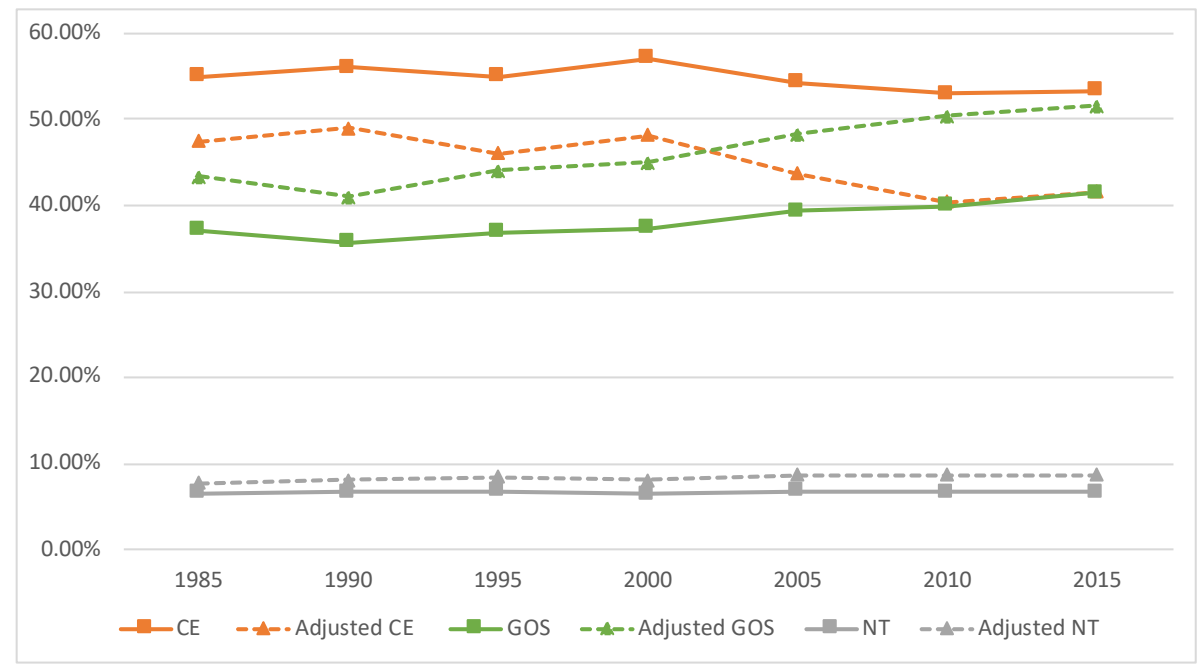

Figure 11: Functional distribution of income before and after adjustments

Source: CEX Tables and the BEA's Use Tables

The standard theory assumes a constant wage share of output; therefore, productivity gains must appear in real wages. However, this is not the case, as Figure 12 shows. Stiglitz (2012) explains this puzzle by rising rent-seeking activities after the 1980s. Monopolies in finance, health, and high-tech industry increased their prices at the expense of all others and did not share productivity gains with their workers. Mazzucato (2018) argues that cash flows arising from productivity gains are used in share buybacks in order to increase shareholder values at the expense of stakeholder values. Taylor and Ömer (2018) point to wage repression in stagnant as well as leading sectors of the economy as a tool of class struggle while giving credit to market power based explanations. Results here are compatible with all explanations, and a decline in wage share turns to stagnation of average compensation after taking out finance, healthcare, and PBS.

\subsection{Possible sources of bias}

One problem with CEX data is that it does not climb up to top incomes because of the nature of the survey. Moreover, the survey depends on what people say about their income and sources of income. Therefore, one might argue that CEX data underestimate the share of capital income in finance, healthcare, and PBS expenditures. It might mainly be a concern for the decomposition of the top $1 \%$ income. If people underreport their capital income, the above analysis might be underestimating the share of GOS in financing health, finance, and PBS expenditures.

In order to test for the bias, the above results are compared with data of 


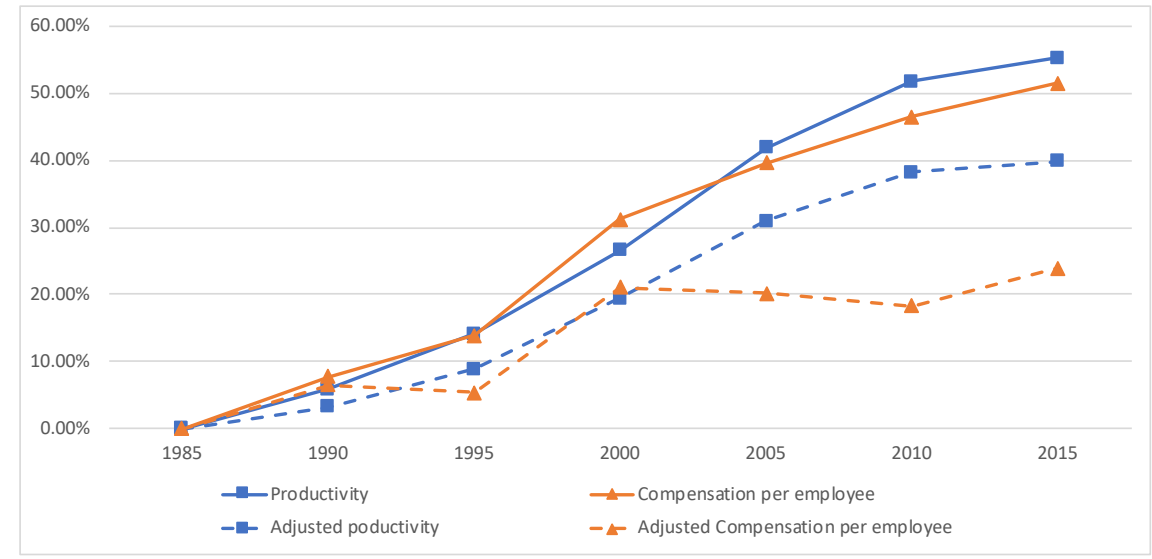

Figure 12: Adjusting productivity and compensation per employee (cumulative growth rates on vertical axis)

Source: CEX Tables and the BEA's Use Tables

Piketty (2014). Piketty gives a decomposition of top US incomes for 2007 in the appendix of his seminal book Capital. His data are coming from tax reports, and it does not suffer from underreporting issues. For comparison, I form four income groups: Low income (bottom 60\%), middle income (60\%-90\%), high income $(90 \%-99 \%)$, and top $1 \%$. Dividing high incomes to top $1 \%$ and top $10 \%$ is to account for rising capital share of incomes accurately. For CE and GOS shares of low income, I again use CEX data of the lowest three quintiles and assume that the decomposition of income of the fourth quintile represents middle-income shares.

For CE and GOS (capital income + mixed-income) shares of top $1 \%$ and next 9\%, I use Piketty data. For income distribution, I again use Piketty data from World Top Incomes Database for each income group. Expenditure shares are taken from CEX, and health and finance-PBS expenditures of high incomes are estimated by using Engel curves derived from CEX. Engel curves describe how expenditures on a good change as income level rises. Engel curves of normal goods are upward sloping, and if the curve bends over expenditures (income) axis as income levels rise, it is a luxury good (necessity). For health and finance-PBS, curves are upward sloping, and they are almost linear. Therefore, I approximate Engel Curves by linear trend lines and estimate expenditure shares of top income groups by entering mean expenditures of high incomes from the World Top Incomes Database. The results for 2007 are summarized in Table 2.

The results in Table 2 are quite similar to CEX results. CE shares with Piketty data are even a little higher than CEX shares. That means the underreporting problem also affects $\mathrm{CE}$ because of high compensations of the top $1 \%$. Therefore, possible underreporting issues do not affect wage and profit-type income shares of finance, healthcare, and PBS expenditures significantly. The 


\begin{tabular}{|c|c|c|}
\hline & CEX (2007) & Piketty (2007) \\
\hline \hline$C E^{\text {health }}$ & $93.9 \%$ & $95.0 \%$ \\
\hline$G O S^{\text {health }}$ & $6.1 \%$ & $5.0 \%$ \\
\hline$C E^{f p b s}$ & $92.8 \%$ & $94.3 \%$ \\
\hline$G O S^{f p b s}$ & $7.2 \%$ & $5.7 \%$ \\
\hline
\end{tabular}

Table 2: Comparing shares using CEX and Piketty data

Source: CEX Tables and World Top Incomes Database

risk of bias in using consumer survey data declines since this study focuses on the decomposition of income rather than levels of income.

\section{Discussion}

The paper contributes to the literature on inequality and measurement of real output growth. The dual criteria described in section 2 is set to explain the stagnation in wages and median income through changing sectoral sources of real output growth. However, it also has an implicit welfare dimension because after finding rapidly growing sectors, the discussion shifts to sectors whose contribution to the final product is controversial.

One of the main drivers of inequality in the US is rising capital share of income. Since capital ownership is very concentrated at the top of the income distribution, rising capital share increases income inequality. There are several explanations for why capital share has risen in the last four decades, even though the standard theory assumes constant factor shares. The main driver is $r>g$ for Piketty (2015), where $\mathrm{r}$ is the rate of return on capital, which has been above the growth rate $(\mathrm{g})$ in advanced economies since the 1980s. With rising capital/income ratio and an elasticity of substitution between labor and capital higher than one, Piketty (2015) predicts that capital share will continue to rise in advanced economies. With the treatment of finance, healthcare, and PBS as intermediate consumption, growth rates decline even more; therefore, $r>g$ dynamic might be more effective for US inequality. Adjustments to functional distribution of income support this claim.

Milanovic (2019) discusses explanations ranging from the decline in cost of capital that made capital usage widespread to monopoly power and changing balance between labor and capital. Taylor and Ömer (2018) point to wage repression as a tool of class struggle. Institutional changes such as weak labor unions and globalization intensify rising inequality. Another explanation for rising inequality is rent-seeking, which is generating income without contributing to social welfare. This happens when firms charge above competitive prices for their products by using their market power. The well-known examples are predatory lending that refers to banks' charging above typical interest rates and drug companies charging excessive prices for their drugs. Stiglitz (2012) 
defines part of the income of banks, drug companies, insurance companies, and lawyers as excess profits above and beyond their social contribution. According to Stiglitz (2012), rent-seeking has distorted US income distribution and increased living costs of ordinary Americans. The findings of the paper are in line with the inequality literature and suggests that the rise in inequality might be more severe than what conventional metrics indicate.

The second strand of the literature that the paper contributes is the measurement of real output and the connection between GDP and welfare. GDP, in the end, is a social and political construct, "a particular mix of statistics, imputations, and implicit assumptions" (Assa, 2018, p. 155); however, it has the power to shape our understanding of economics in addition to its role in policy debates and political rivalries. Current national accounts were born in the days of the second world war and just after the economic depression. With the rise of Keynesian theory, governments took active responsibility in shaping their economies. The idea behind official national accounts was to provide governments a reliable estimate so that they could measure the effects of policies in order to steer growth.

Although GDP is a political instrument, supposed to measure production, first national accountants saw a link from national product to economic welfare because construction of GDP was not only a technical task. Economic theory, values, and social needs played essential roles in deciding what to include in GDP estimations. Kuznets (1951), who is the founder of US national accounts, points to the importance of goals of economic activity in shaping those decisions.

The term 'net' implies that products are distinguished with reference to some set of goals, whose satisfaction is treated as a positive contribution. If by social welfare we mean a positive contribution to some socially determined set of goals, it is clear that 'net product' is an approximation to net additions to social welfare. I don't mean to imply that national income can be an accurate measure of social welfare, but it must be viewed as an approximation to it, since any measure of net product is an approximation to it (p. 179).

There must be a link from GDP to additions to welfare because final products are determined concerning social goals. Eisner supports Kuznets: "Our accounts may better seek to measure not welfare itself but the nation's output of final goods and services, which are presumed to contribute to welfare" (Eisner, 1988, p. 1617). Research on economic welfare became popular during the 1960s, and 70's when advanced economies were experiencing record rates of growth, which created concerns about the welfare dimension, such as the environmental costs. As a response to anti-growth concerns, Nordhaus and Tobin (1972) developed a measure of economic welfare with shifting many services from final to intermediate consumption, imputing a value for leisure and housework, and subtracting disamenities of urban life from national product. After these adjustments, Nordhaus and Tobin (1972) observed that growth was not obsolete, and national accounts were pointing to the correct direction even though 
they were not perfect. Vanoli (2005) reports many other attempts following this path during the 1960s and the early 1970s. However, the stagflation of the 1970s stopped them: "Times have changed, and unemployment is back, again focusing the attention on growth itself" (Vanoli, 2005, p. 293). High growth rates of golden years have never turned back.

The measurement of real output has been becoming popular again recently due to jobless recoveries, the productivity gap, and stagnation in standards of living even though GDP per capita continues to "grow". Stiglitz et al. (2010) discuss issues with GDP by mentioning its inconsistencies with well-being in general. The primary advice is to go beyond GDP with improved measures of individual and social welfare. Stiglitz et al. (2010) also argue the scope of defensive expenditures, which are socially necessary fixed costs, and recommend to shift healthcare expenditures to investment under the maintenance of health capital. Basu and Foley (2013) subtract FIRE, healthcare, education, PBS, and government from value-added because these services do not have independent output measures. National income accounts impute a value-added to these services based on their revenues less expenses. Since these services produce more of the US value-added today, the low correlation between recent GDP figures and employment may be related to how we measure these services. Basu and Foley (2013) find that measurable part of value-added is strongly correlated with employment. Assa (2016) focuses on FIRE services and treats the output of finance as an intermediate product of the economy, and arrives at a measure which is highly correlated with employment and median income trends.

Following Kuznets-Eisner-Nordhaus and Tobin (1972), and current contributions of Basu and Foley (2013) and Assa (2016), this paper explores the role of finance, healthcare, and PBS in macroeconomic measurement of growth and distribution in recent decades. Assa's argument is extended to healthcare and $\mathrm{PBS}^{18}$ because these services meet the dual criteria described above: They have accounted for more of the post-1973 growth compared to 1947-1973, and their contribution to final uses of households are controversial.

\section{Conclusion}

The 1980s were the years of the shift from Keynesian welfare state policies to the neoliberal policy agenda in the US (and other Western economies). These policies aimed at increasing profit rates through attacking labor unions, deregulating labor markets, and cutting government spending on healthcare and other social benefits. Changes in the sectoral structure of the economy from manufacturing to services have accompanied the policy shift. As a result, growth rates remained high with the ever-expanding healthcare, finance, and professional services, whereas median income and real wages have stagnated. The treatment of these services as costs of the economy implies lower growth rates and makes the burden of neoliberal policies on society heavier.

\footnotetext{
${ }^{18}$ Unlike Assa (2016), I start with expenditures side of accounts and shift final expenditures to intermediate consumption block. The product side of accounts are reconciled subsequently.
} 
After adjustments, the consumption share of GDP in 2016 declines below its level in 1947, showing that consumerism has brought lower consumption after taking out finance, healthcare, and PBS. In conventional accounts, the investment share of GDP declines despite rising profits after 1980, thus creating a profit-investment puzzle. In adjusted expenditures, investment share stays constant over 1980-2016 and offers a measurement dimension to the puzzle. Government share rises to almost one-fourth of GDP, which points to a larger room for fiscal policy.

On the income side of conventional accounts, the GOS share of output rises vis-a-vis $\mathrm{CE}$ share after 1980. The $\mathrm{CE}$, however, includes income spent on finance, healthcare, and PBS, which are treated as intermediate consumption in the paper. Therefore, after adjustments, the CE share of output declines more than the conventional share as almost all expenditures on finance, healthcare, and PBS are financed out of the CE. Adjusted CE per employee stagnates after 2000 even though adjusted labor productivity continues to grow, thus creating a productivity gap. The current treatment of NIPAs not only overestimates growth and consumption but also obscures the sharper wage-profit inequality, thus showing American capitalism better performing and less unequal.

\section{References}

Assa, J. (2015). Financial output as economic input: Resolving the inconsistent treatment of financial services in the national accounts. Working Paper 01/2015, Department of Economics, The New School for Social Research.

Assa, J. (2016). The Financialization of GDP: Implications for economic theory and policy. Routledge.

Assa, J. (2018). Finance, social value, and the rhetoric of gdp. Finance and Society, 4(2):14458.

Basu, D. and Foley, D. K. (2013). Dynamics of output and employment in the us economy. Cambridge Journal of Economics, 37(5):1077-1106.

Christophers, B. (2011). Making finance productive. Economy and Society, 40(1):112-140.

Eisner, R. (1988). Extended accounts for national income and product. Journal of Economic Literature, 26(4):1611-1684.

Foley, D. K. (2013). Rethinking financial capitalism and the "information" economy. Review of Radical Political Economics, 45(3):257-268.

Goodwin, N., Harris, J. M., Nelson, J. A., Roach, B., and Torras, M. (2015). Macroeconomics in context. Routledge.

Hood, K. K. (2013). Measuring the services of commercial banks in the national income and products accounts. Survey of current business, 93:8-19.

Kuznets, S. (1951). Government product and national income. Review of Income and Wealth, $1(1): 178-244$.

Kuznets, S. (1953). Economic change: selected essays in business cycles, national income, and economic growth. Greenwood Pub Group.

Mazzucato, M. (2018). The value of everything: Making and taking in the global economy. Hachette UK.

Milanovic, B. (2019). Capitalism, Alone: The Future of the System That Rules the World. Harvard University Press.

Nordhaus, W. D. and Tobin, J. (1972). Is growth obsolete? In Economic Research: Retrospect and prospect, Volume 5, Economic growth, pages 1-80. Nber.

Piketty, T. (2014). Technical appendix of the book capital in the twenty-first century. Paris School of Economics, pages 49-52. 
Piketty, T. (2015). About capital in the twenty-first century. American Economic Review, 105(5):48-53.

Piketty, T., Saez, E., and Zucman, G. (2017). Distributional national accounts: methods and estimates for the united states. The Quarterly Journal of Economics, 133(2):553-609.

Stiglitz, J. E. (2012). The price of inequality: How today's divided society endangers our future. WW Norton \& Company.

Stiglitz, J. E. (2019). People, power, and profits: Progressive capitalism for an age of discontent. WW Norton \& Company.

Stiglitz, J. E., Sen, A., and Fitoussi, J.-P. (2010). Mismeasuring our lives: Why GDP doesn't add up. The New Press.

Studenski, P. (1961). The income of nations. New York University Press.

Taylor, L. and Ömer, Ö. (2018). Where do profits and jobs come from? employment and distribution in the us economy. Working Paper No.72, Institute for New Economic Thinking.

Taylor, L. and Ömer, Ö. (2019). Race to the bottom: Low productivity, market power, and lagging wages. International Journal of Political Economy, 48(1):1-20.

Vanoli, A. (2005). A history of national accounting. IOS press. 


\section{Appendix A Adjustments to GDP by the value- added}

After subtracting final expenditures recorded under finance, healthcare and PBS rows of the Input-Output (I/O) Use Tables of the BEA from consumption, investment, net exports, and government spending columns, the next step is to distribute the deduction to intermediate consumption of industries and adjust income side of accounts. As a first approximation, I keep value-added shares and income distributions constant because this approach does not require further information about value-added decomposition of the deduction and which type of income is spent on these services.

In table A1, I discuss my methodology in a hypothetical economy, which produces only two commodities: A and B. Final expenditures on commodity A (B) is $\$ 10$ billion ( $\$ 20$ billion), and intermediate consumption is $\$ 15$ billion ( $\$ 13$ billion). Total income is distributed to CE and GOS equally, and NT is zero because there is no government. However, income distribution over industries is different as industry A is profit, and industry B is wage heavy. On the value-added, each industry has a share of $50 \%$, and I use this ratio to treat expenditures on commodity B as intermediate consumption of the economy in Table A2.

Table A1: I/O Use Table before adjustments (in billions of dollars)

\begin{tabular}{|c|c|c|c|c|c|c|c|c|}
\hline & Ind.A & Ind.B & C & I & NX & G & GDP & Total output \\
\hline \hline Commodity A & 5 & 10 & 5 & 5 & 0 & 0 & 10 & 25 \\
\hline Commodity B & 5 & 8 & 15 & 5 & 0 & 0 & 20 & 33 \\
\hline CE & 3 & 12 & & & & & & \\
\hline NT & 0 & 0 & & & & & & \\
\hline GOS & 12 & 3 & & & & & & \\
\hline Total VA & 15 & 15 & & & & & 30 & \\
\hline Total output & 25 & 33 & & & & & & 58 \\
\hline
\end{tabular}

In table A2, I shift final expenditures on commodity B to intermediate consumption. GDP by the expenditures declines by $\$ 20$ billion. I distribute this amount to intermediate consumption of industries equally; thus, GDP by the product also declines to $\$ 10$ billion. I subtract the total amount from incomes of industries with keeping income distributions constant, i.e., CE of industry A (B) declines to $\$ 1$ billion ( $\$ 4$ billion) and GOS of industry A (B) declines to $\$ 4$ billion ( $\$ 1$ billion). Total output row and column stay constant since I only change the decomposition of the output.

I prefer keeping relative value-added constant instead of absolute valueadded because the focus of my research is the macroeconomic analysis of adjustments instead of an industry-level investigation. This is not an arbitrary adjustment because value-added is not an observed category. In the end, it is a residual after taking out intermediate consumption from the output of indus- 
Table A2: I/O Use Table after adjustments (in billions of dollars)

\begin{tabular}{|c|c|c|c|c|c|c|c|c|}
\hline & Ind.A & Ind.B & C & I & NX & G & GDP & Total output \\
\hline \hline Commodity A & 5 & 10 & 5 & 5 & 0 & 0 & 10 & 25 \\
\hline Commodity B & 15 & 18 & 0 & 0 & 0 & 0 & 0 & 33 \\
\hline CE & 1 & 4 & & & & & & \\
\hline NT & 0 & 0 & & & & & & \\
\hline GOS & 4 & 1 & & & & & & \\
\hline Total VA & 5 & 5 & & & & & 10 & \\
\hline Total output & 25 & 33 & & & & & & 58 \\
\hline
\end{tabular}

tries. My treatment does not change the total output of industries as Tables A1, and A2 clearly show.

An alternative way for adjustments might be to shift the value-added of finance, healthcare, and PBS to intermediate consumption and impute the deduction to GDP by the expenditures. The advantage of this approach is that taking out value-added directly adjusts GDP by the income. However, distributing the deduction to intermediate consumption of industries is still non-trivial, and it requires additional assumptions. However, more importantly, the value-added of an industry is not necessarily equal to expenditures on that industry, as Table 1 shows. My argument here is about the treatment of healthcare, finance, and PBS expenditures of households as intermediate consumption. I do not argue that these services do not produce any value. Therefore, I start adjustments from the expenditures and impute the same deduction to the value-added and income of each industry. Table A3 shows how this methodology applies to 2016 I/O Use Tables.

Table A3 divides the economy into health, finance, PBS, and the rest. Intermediate consumption on health is negligible, whereas most of the output of PBS $(73 \%)$ is used as inputs by other industries. On the expenditures, most of the final uses of health and finance are consumption expenditures, and investment is the most significant expenditure on PBS. The US economy has a trade surplus in finance and PBS, but a small deficit in health services. Government spending on PBS is significant due to the R\&D investments of the US government. On the value-added side, PBS has a share of $12 \%$, which is followed by finance $(10 \%)$ and the health industry $(7 \%)$. These ratios are used in adjusting health, finance, and PBS in Table A4.

In Table A4, all final expenditures on health and finance are shifted to intermediate consumption of industries according to their value-added shares. I only shift consumption expenditures and net exports of PBS to intermediate consumption because the rest is private and public investment in intellectual property products. GDP by the output and GDP by the expenditures decline to $\$ 14,667$ billion from $\$ 18,624$ billion. 
Table A3: Health, finance and PBS in 2016 (billions of current dollars) - before adjustments

\begin{tabular}{|c|c|c|c|c|c|c|c|c|c|c|}
\hline & Health & Finance & PBS & Rest & C & I & NX & G & GDP & Output \\
\hline \hline Health & 26 & 0 & 0 & 23 & 2,438 & 0 & -2 & 0 & 2,436 & 2,485 \\
\hline Finance & 279 & 847 & 215 & 908 & 988 & 143 & 83 & 0 & 1,214 & 3,463 \\
\hline PBS & 269 & 404 & 622 & 1,776 & 254 & 662 & 51 & 187 & 1,154 & 4,225 \\
\hline Rest & 381 & 409 & 533 & 6,769 & 9,141 & 2,252 & -653 & 3,081 & 13,821 & 21,912 \\
\hline VA & 1,349 & 1,835 & 2,252 & 13,188 & & & & & 18,624 & \\
\hline Output & 2,304 & 3,496 & 3,622 & 22,664 & & & & & & 32,085 \\
\hline
\end{tabular}

Source: The BEA's Use Tables

Table A4: Health, finance and PBS in 2016 (billions of current dollars) - after adjustments

\begin{tabular}{|c|c|c|c|c|c|c|c|c|c|c|}
\hline & Health & Finance & PBS & Rest & C & I & NX & G & GDP & Output \\
\hline \hline Health & 197 & 244 & 292 & 1753 & 0 & 0 & 0 & 0 & 0 & 2,485 \\
\hline Finance & 364 & 968 & 361 & 1,770 & 0 & 0 & 0 & 0 & 0 & 3,463 \\
\hline PBS & 290 & 435 & 659 & 1,993 & 0 & 662 & 0 & 187 & 849 & 4,225 \\
\hline Rest & 381 & 409 & 533 & 6,769 & 9,141 & 2,252 & -653 & 3,081 & 13,821 & 21,912 \\
\hline VA & 1,072 & 1,439 & 1,777 & 10,379 & & & & & 14,667 & \\
\hline Output & 2,304 & 3,496 & 3,622 & 22,664 & & & & & & 32,085 \\
\hline
\end{tabular}

Source: The BEA's Use Tables 